\title{
Earthquake-Resistant Design Principles of the Traditional House in Lombok Island
}

\author{
Fajar Aswadi Syamsuri ${ }^{1}$, Heru Sufianto ${ }^{2 *}$ \\ ${ }^{1,2}$ Department of Architecture, Faculty of Engineering, Universitas Brawijaya, Malang, Indonesia \\ *Corresponding author. Email: hsufianto@ub.ac.id
}

\begin{abstract}
Indonesia lies above one of the active three tectonic plates on earth, which causes earthquake disasters frequently. In 2018 the island of Lombok was hit by a 7.0 Richter Scale earthquake creating major destruction of buildings. While most of the modern building construction damaged when hit the waves, some of the traditional houses in the Segenter region remained steady and safe from the disaster. This study examines the structural and construction system of some traditional houses safe from the waves in Lombok. It focuses on the views of the geometry of building, joint of structure-construction system, as well as building materials applied. Field observation was held to understand the details of constructions. Collected data were analyzed based on earthquake resistance design principles. The outcomes of this study would be beneficial for modern house designs in the future.
\end{abstract}

Keywords: Traditional house, earthquake, structural system, construction

\section{INTRODUCTION}

Indonesia is a country located between the Pacific Ring of Fire and local tectonic faults, which spread across its sea and island. It causes Indonesia is susceptible to hazards from earthquake disasters. An earthquake with 7.0rs (Richter scale) stroke Lombok Island in July 2018. It causes major damage to most buildings, such as houses, offices, schools, villas and other important facilities. Approximately $60 \%$ of buildings were collapsed to the ground. The Indonesian government and building experts were curious for such catastrophe, whether buildings were poorly designed (earthquake resistance) or inadequate building requirements have been implemented.

Beyond the destruction of most existing (modern) buildings, some traditional residential buildings located in Segenter village remain standing firmly. It is interesting to understand the capability of traditional buildings to withstand the earthquake. This study was looking for reasons for such construction that remain standing when hit by the heavy earthquake through details of buildings, especially the structure system, which caused buildings resistant from a strong earthquake. Understanding the details of traditional house construction would be beneficial for developing design principles in the future to avoid major damage to building construction.

\section{RESEARCH METHODS}

This research was conducted by analyzing data collected from the Segenter village. Numbers of data were gathered, including typical materials of traditional buildings; typical connection systems of building construction included beams, columns, walls, and roofs; typical building substructures system as well as the geometry of buildings. All data were collected during fieldwork. Several traditional houses were chosen based on certain criteria and used as the sample of this study. Collected data were analyzed through comparing details of existing residentials toward references of building design principles generally suggested at the earthquake area. The outcomes were descriptively elaborated as a potential solution for improving building construction implementable for the near future in Indonesia.

\section{RESULT AND DISCUSSION}

Traditional Sasak tribe houses are generally rectangular. The walls are made of woven bamboo, but now there are several houses with brick walls. Both are still traditional roofed, which is in the form of a pyramid with a thatch roof. All of the traditional houses are still in soil floors.

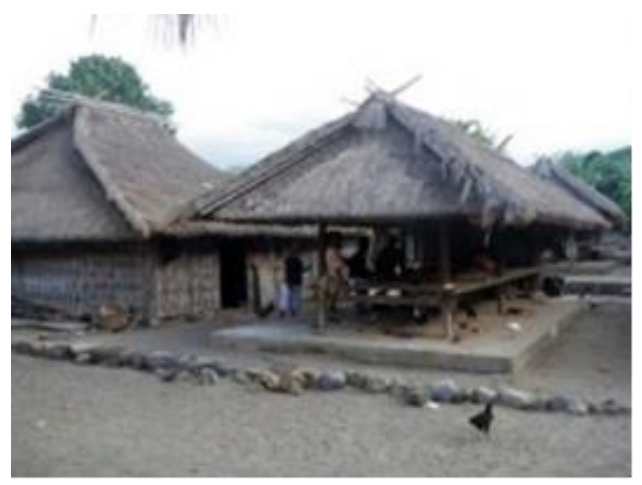

Figure 1 Traditional House in Segenter Village 
In the village of Segenter, usually, one generation builds a house in one area. The parents 'house is on the East side, while the children occupy the house located in front of the parents' house (on the West side). The two houses face each other with a berugak separator in the middle. The berugak was built with a size of about $4 \times 6$ meters, which functioned as a place for chatting between parents and children. As well as being a place to study together and receive guests. (Figure 1)

The village of Segenter is indeed the right place to see the traditional design of the Sasak tribe. Their houses are made of simple natural materials in a row and neatly arranged in the village. The walls of Segenter Village residents' houses are made of bamboo with a roof made of straw. The floor is mainly in the form of clay with a row of stones surrounding the house into a fence. Although it looks simple, but this house is quite strong and well-maintained. For home maintenance, the occupants used to use materials provided directly by nature; for example, just to make the floor more durable and more beautiful, at certain times, the population will polish cow dung so that the floor remains slippery and durable. The roof covering is frequently replaced in every 12 to 13 years.

\subsection{Structural Configuration}

The typical structures of the Segenter traditional house consist of columns and beams connected through a simple wood joint technique tied by a rope (straws) as they are mainly made from timber materials. Tie rope was found in roof construction, which made form bamboo and straws as well. The lightweight roof material is found effective to resist earthquake shake. Meanwhile, rope ties, to some extent, enable to accommodates $\mathrm{x}$ and $\mathrm{y}$ moving direction. Geometrically, the traditional house at Segenter is a symmetrically-rectangular building, with $10 \mathrm{~m}$ wide and $12 \mathrm{~m}$ long (Figure 2). This form is eventually found effective in responding to the earthquake as it is suggested in the Indonesian earthquake building design standard [1]. Following the layout, the foundation form of these houses is typically ordered symmetrically arranged by the layout (Figure 3).

Structural loads are an important consideration in a building. The building structures should be designed and built to safely resist all actions (vertical and horizontal movement) that they are most likely to face anytime. Both dead load or live load of the building should be firmly distributed systematically through structural elements of the building, from top of building toward footing. The elements may involve beams, columns, and foundations. The more rigid connectors among structural elements, the weaker of buildings resisting vertical and horizontal movements caused by earthquakes.

The building foundations of the traditional house are placed surrounding the building plan, followed by the placement of structural columns on each foundation. The structural beams placement of Dusun Segenter Traditional House also follows the building plan outer line, extending to each column of the building, between columns and beams are reinforced with elbows. A simple-shaped building plan will make it easier for structures to be arranged in a modular manner. Placement of foundation points, column points, and beams that can be easily adjusted to the shape and axis of the building plan, make the building have evenly distributed load of capacity so that it is resistant to earthquake shocks $[2,3]$.

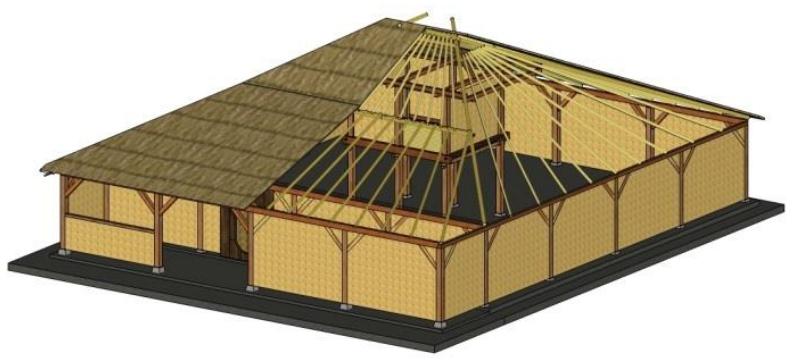

Figure 2 Typical construction system
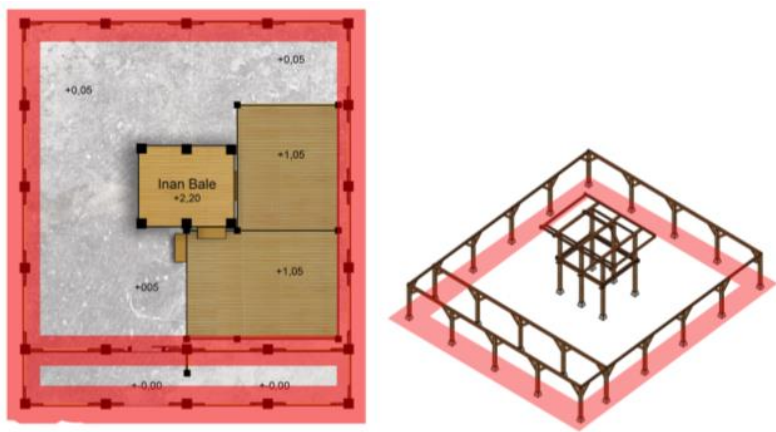

Figure 3 Typical sub-structure design
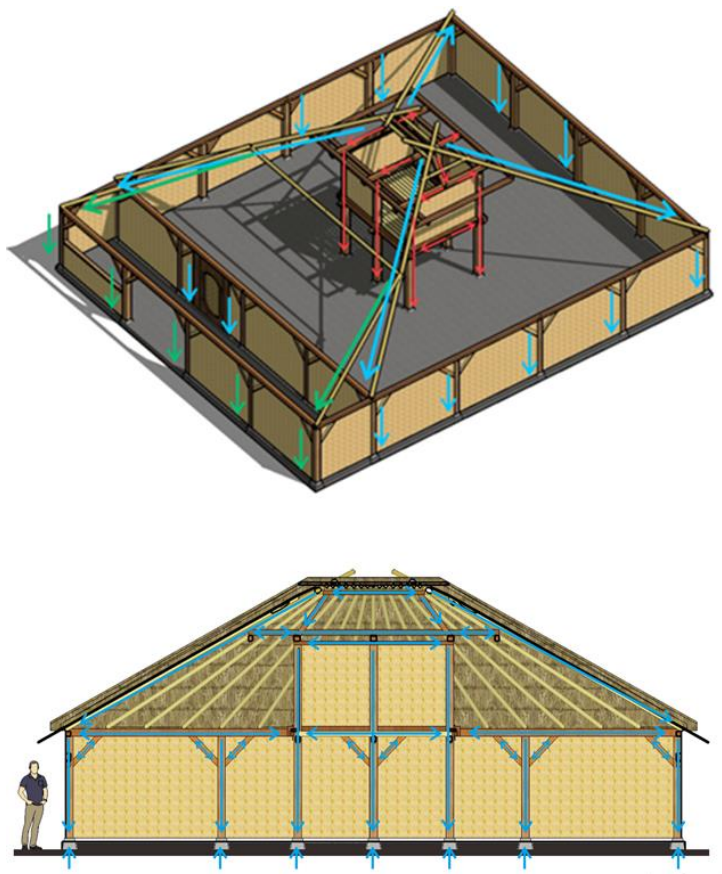

Figure 4 Distribution of loads on structural columns and beams 


\subsection{Joint Construction}

The Dusun Segenter Traditional House uses a non-bonded joint for the foundation and columns connections, which gives the connection ability to slip during an earthquake strikes, this ability allows the foundation to reduce the distribution of earthquake waves to the columns and other elements above the foundation. Similarly, this connection system is applied between the roof hip frame and beams. The slip connection is capable of distributing the force between beams and hip frame when shaking.
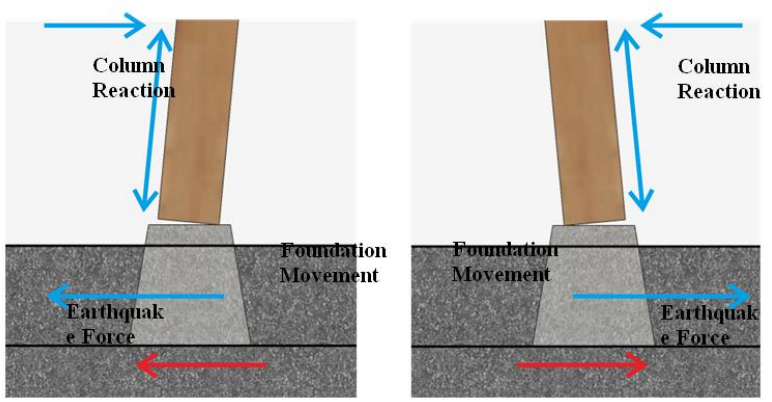

Figure 5 The force reaction between column and foundation

The walls are generally made from the woven bamboo panel with $3 \times 2 \mathrm{~m}$ for each panel. The panel is attached to columns and tied with palm ropes. Woven bamboo panels have a very light density as the occupants may only use a palm fiber knot technique to attach the panels to the structural column (Fig. 6). The knot connection between woven bamboo panels and the structural column allows the joint to move slightly, adjusting the earthquake load that spreads all over the structures of the building. Therefore, walls are barely effecting the building structure when an earthquake occurs.

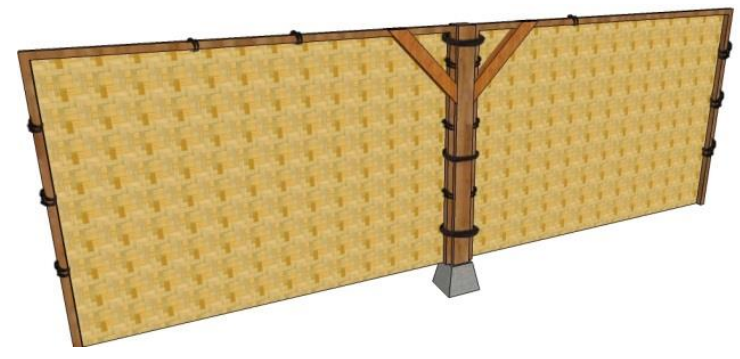

Figure 6 Joint connection between walls and columns

The connection system between columns and beams is mainly in the form of tip \& hole-joint with a clasp character. The small cavity of the joint will allow structural connection to move slightly, adjusting the earthquake waves to distribute the force toward columns consistently. The tip \& hole-joint between structural elements create a mutual attraction of force so that the joint is not easily off or broken during an earthquake shock [4]. An elastic construction is a construction that can deform following the direction of the earthquake shock so that the structural joint is spared from sudden brittle collapse and can return to its original form when the earthquake strike is completed [3]. According to Joglo Traditional House construction, a clasp character of a wooden joint would make the building to be able to withstand the earthquake force because the clasped joint applies the principle of elastic construction [5].

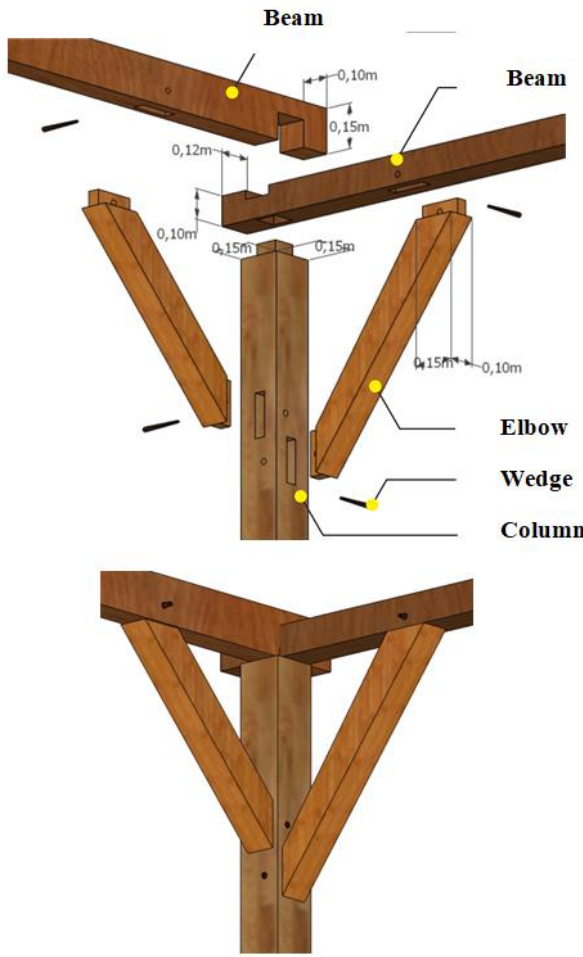

Figure 7 Construction of joints between structural column and beams

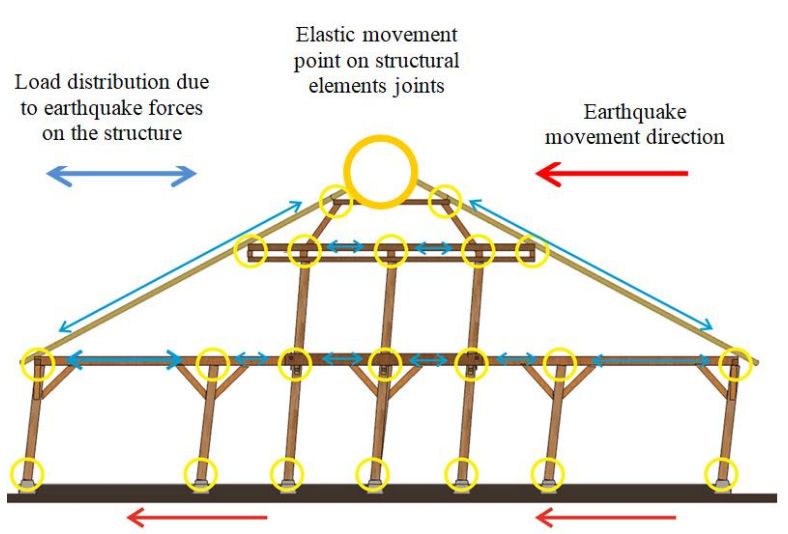

Figure 8 Illustration of structural deformation in Dusun Segenter traditional house during the earthquake

\subsection{Materials}

Mountain stones are used for the material of the building foundation. As the main buffer of whole buildings, the foundation importantly takes part to stabilize the building 
when an earthquake occurs. Located at the base point of each column, stone materials would be the largest density materials $(1,500 \mathrm{~kg} / \mathrm{m} 3)$ from other structural elements of the building. [6]. From field survey, it was found that only about a quarter part of the foundation is above the ground/ topsoil, while the rest of three quarter buried inside. This plate, therefore, would be beneficial to respond to horizontal movement from earthquakes.

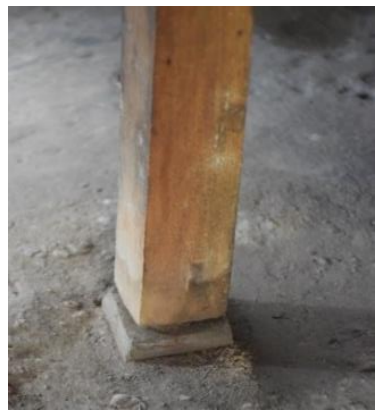

Figure 9 Stone materials as the building foundation

For the roof easel frame, a local wood material, namely Kecapi wood, is used; this material has $550 \mathrm{~kg} / \mathrm{m} 3$ weight [7]. While hip frames, rafters, and battens are generally made from bamboo material with a density of $610 \mathrm{~kg} / \mathrm{m} 3$ [8]. Bamboo material does have a considerable density when compared to Kecapi wood, which is used as a roof easel. Bamboo, in its intact state, has an air cavity at the center, different from Kecapi wood that has more dense volume without cavities. In the same size, bamboo material, therefore, will be lighter and suitable for roof construction materials.

The lightest building material implemented in Segenter house is dried reed grass for a roof covering, and woven bamboo panels used for walls. The placement of building materials of the Segenter house eventually following the principle of material application for earthquake-resistant designs, which should place greater density at the bottom or lower part of the building. [1].
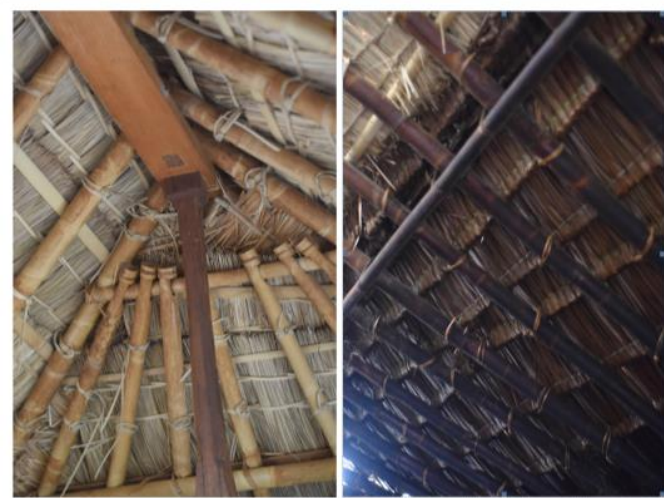

Figure 10 Kecapi wood as roof easel frame, and bamboo as roof rafter frame

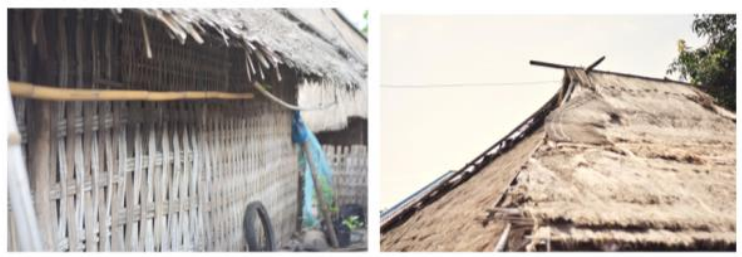

Figure 11 Woven bamboo panel as wall material, and dried reed grass as roof

The summary of earthquake-resistant design principles implemented in the Segenter Traditional House is presented in the Figure 12 and 13.

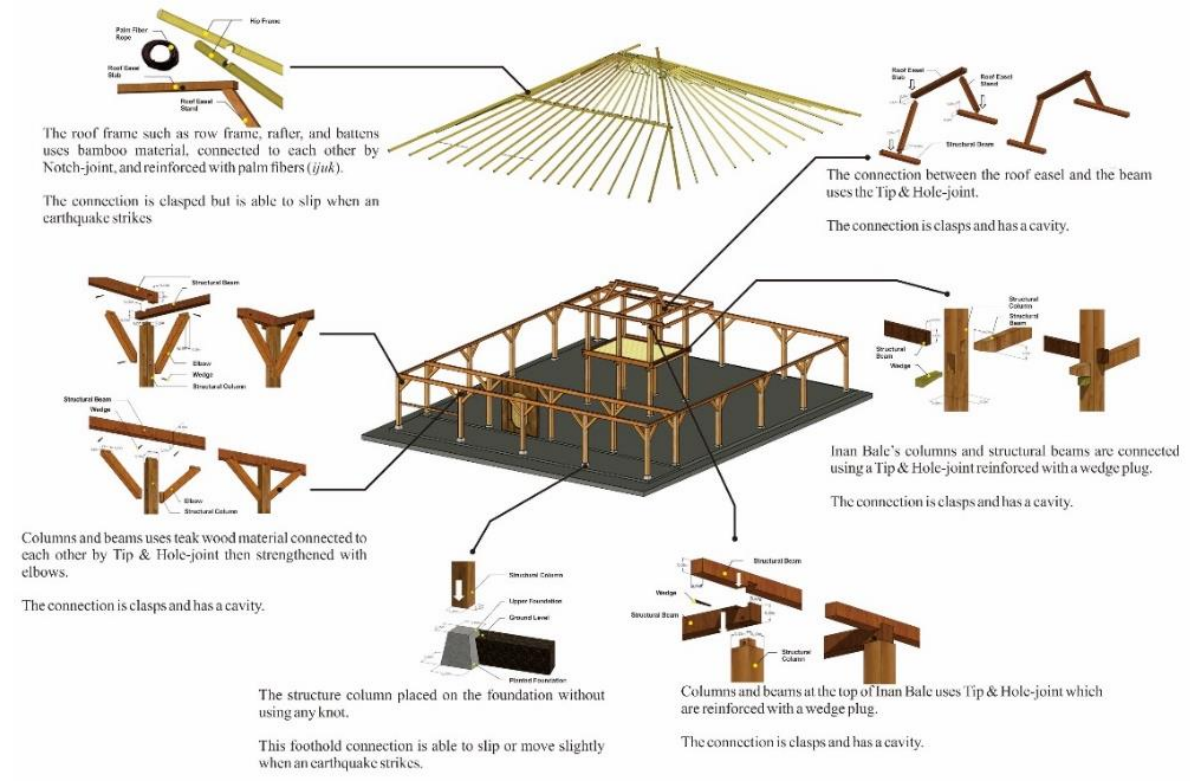

Figure 12 Illustration of various joints applied in Dusun Segenter Traditional House (1) 


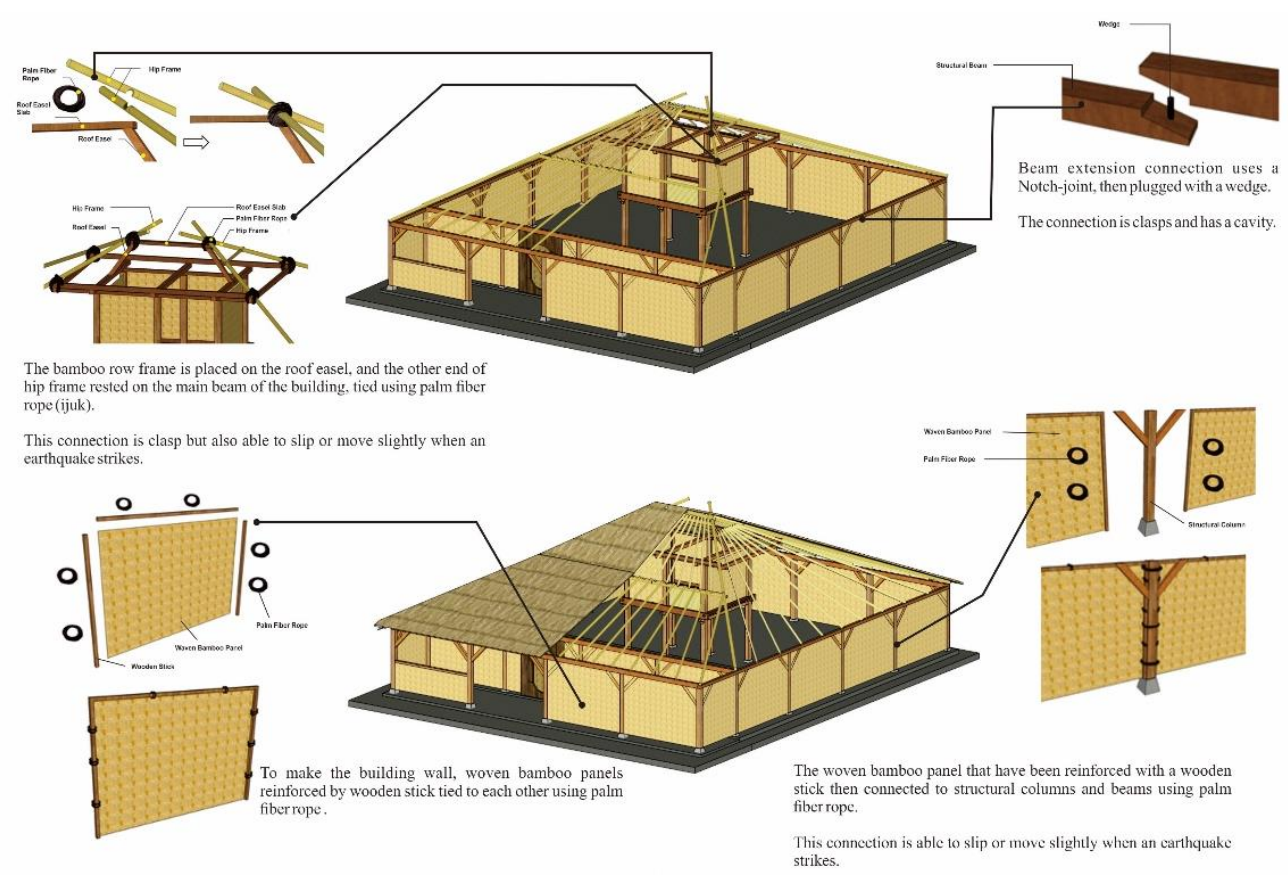

Figure 13 Illustration of various joints applied in Dusun Segenter Traditional House (2)

\section{CONCLUSION}

The Segenter traditional house that was built hundreds of year ago and maintained over generations has been accommodating earthquake-resistant building design principles. Several reasons for these building to remain standing during a strong earthquake include:

- The building is design in a simple plan and symmetrical

- Foundation points and structural elements above of the building follows the shape and axis of the building plan

- The connectors among roofs, beams, columns of the building are designed with elastic character anticipating lateral movements and swing.

- The foundation of buildings is designed to anticipate slip against the structure above.

- Most of the building materials are lightweight, and they are located symmetrically throughout the layout.

\section{REFERENCES}

[1] A. Widjanarko, Pedoman Teknis Bangunan Tahan Gempa, Departemen Pekerjaan Umum, Direktorat Jenderal Cipta Karya, 2006.

[2] H. Sunansyah, N. E. Yulita, Prinsip Rumah Srotong Suku Samin Sebagai Dasar Perancangan Rumah Tinggal Tahan Gempa, Universitas Brawijaya, Fakultas Teknik, Malang, 2018.
[3] N. S. Sahay, Penerapan Bentuk Desain Rumah Tahan Gempa. Jurnal Perspektif Arsitektur, 2010.

[4] B. W. Maer, Respon Pendopo Joglo Jogjakarta Terhadap Getaran Gempa Bumi. Jurnal Dimensi Teknik Arsitektur, 2008.

[5] Y. O. Prihatmaji, Perilaku Rumah Tradisional Jawa Joglo Terhadap Gempa, Jurnal Dimensi Teknik Arsitektur (2007).

[6] Badan Standarisasi Nasional, Spesifikasi Desain Untuk Konstruksi Kayu SNI 7973:2013, Jakarta: BSN, 2013.

[7] T. Priadi, D. S. Maretha, Sifat Keawetan dan FisisMekanis Kayu Kecapi dan Rambutan setelah Perlakuan Pemanasan Minyak sebagai Upaya Peningkatan Mutu Kayu Ramah Lingkungan, Fakultas Kehutanan, Institut Pertanian Bogor, 2015

[8] A. Anas, Karakteristik Bilah Bambu Dan Buluh Utuh Pada Bambu Tali Dan Bambu Ampel. Departemen Hasil Hutan. Fakultas Kehutanan, Institut Pertanian Bogor, 2012 